\title{
A Transformation into Digitally Supported Education: Case from the State University of Zanzibar
}

\author{
Umayra El Nabahany ${ }^{1}$, Anne-Marie Mosbech² ${ }^{2}$ Mwanajuma Mgeni ${ }^{1}$, Said Yunus ${ }^{1}$ \\ ${ }^{1}$ State University of Zanzibar, SUZA, Zanzibar, Tanzania \\ ${ }^{2}$ University of Copenhagen, UCPH, Denmark \\ \{umayra.al-nabhany, \\ mwanajuma.mgeni, said.yunus\}@suza.ac.tz, \\ anne-marie@sund.ku.dk
}

\begin{abstract}
The case discussed in this paper shares lessons learned from the project on how to build sustainable institutional capacity in e-learning environment at the State University of Zanzibar. The project was carried out in partnership with the University of Copenhagen as part of the larger Building Stronger University, BSU program funded by the Danish International Development Agency, Danida.
\end{abstract}

Keywords: institutional capacity building digitally supported education, digital learning, e-learning.

\section{Introduction}

The use of educational technologies in higher education has increased over the last decades. A considerably large number of universities have by now a Learning Management System (LMS) which as a minimum is used to effectively distribute course content to students. Many other types of digital programs, tools and resources are embedded in the higher education teaching too. While a lot of attention seems to be focusing on the technological development and initiatives from few front movers, less attention seems to be given to the broad institutional capacity needed to build a sustainable model for scaling up a skilled u Use of ICT in education at SUZA

The following section describes the overall approach and specific activities jointly supported and facilitated by SUZA and the University of Copenhagen while the Section 3 describes lessons learned throughout the BSU ${ }^{1}$ programs specific work packages.

1 “The Building Stronger Universities program aims at increasing the capacity of African universities in selected Danida priority countries to undertake teaching, research and outreach with the overall objective to generate and apply new knowledge to solve priority development challenges.” 


\section{Use of ICT in Education at SUZA}

E-learning at SUZA can be traced back to 2006 where a very simple e-learning tool for distributing lesson notes in text formats to students was implemented. Because of very limited use of ICT in education at SUZA, the first BSU partnership, in 2011, decided to improve student and teacher access to course materials by implementing the Learning Management System, MOODLE. Since the implementation of MOODLE in 2012 until 2018 a much broader variety of activities have taken place with the aim to support new online and blended learning approaches. Activities covered; 1) capacity development (including educational video production, OER integration and production), 2) mapping of students and lecturers' use of ICT and MOODLE and 3) development of guidelines and procedures. The following sections describe these different activities.

\subsection{Activity 1: Skills development}

\section{ICT staff and Lecturers}

The experience shows that, only few lecturers and IT staff have the opportunity or skills to transform traditional teaching and course material types into digitally supported education without any help or incitement from experienced colleges and management. This is why staff capacity building has been an essential part of the BSU project. Since the SUZA MOODLE has become the backbone for online and blended learning formats since 2014, a series of hands-on workshops have trained IT staff and lecturers' capacity on the use of the MOODLE platform. As it shows in Table 1 below, the training has expanded to all 7 faculties by year 2018.

Table 1. Number of SUZA lecturers and ICT staff trained in the use of MOODLE during the period 2014-2018 and gradually including more campus - as part of the BSU II and BSU III programs $^{2}$.

\begin{tabular}{|c|c|c|c|c|c|c|c|c|}
\hline Year/Campus & SoE & $\begin{array}{l}{ }_{3}^{2} \text { SNSS } \\
3\end{array}$ & $\mathrm{SCOPE}^{4}$ & SKFL $^{5}$ & $\begin{array}{l}\text { SHMS } \\
6\end{array}$ & $\mathrm{SoB}^{7}$ & IoT $^{8}$ & $\begin{array}{l}\text { Total } \\
\text { Number } \\
\text { of Staff } \\
\text { Trained }\end{array}$ \\
\hline $2014+2015$ & & & & & & & & 25 \\
\hline 2018 & & & & & & & 2 & 30 \\
\hline Total number & & & & & & & & 55 \\
\hline
\end{tabular}

2 SoE (School of Education), SNSS (School of Natural and Social Sciences), SCOPE (School of Continuing and Professional Education), SKFL (School of Kiswahili and Foreign Languages), SHMS (School of Health and Medical Sciences), SoB (School of Business), IoT (Institute of Tourism) 
During workshops, lecturers and ICT staff have been trained on basic level on how to set up a course room, structure course content, create student engaging taskssuch as quizzes, discussion forums and online collaboration to develop courses

On a next level, workshops focused on production of simple educational videos and how to critically evaluate and incorporate externally produced Open Education Resources (OER) into the existing SUZA accredited courses.

Further, and with the aim to strengthen evidence-based knowledge at SUZA as well as the institution's positioning, a group of researchers were trained in formulating educational research projects, specifically with regard to didactic and pedagogical strategies for online and blended learning.

Finally, 5 staff from SUZA Center for Digital Learning, CDL, were trained in a slightly different way. Staff from CDL were trained through a combination of a hands- on workshops and on-the side job-training during a pilot production of educational field research videos in 2017. The purpose of the training was to enable SUZA to independently produce high quality materials for the accredited courses as well as for broader dissemination as OER

The center has video recording and editing facilities and staff supporting lecturers in planning and producing course content for digital delivery. CDL staffs were trained in project planning, script writing, video recording, video editing, graphic production and animation. Simultaneously, selected SUZA researchers received basic media training and gained experience on how to open up and disseminate their research and research methods. High quality SUZA OER made CDL staff and researchers experience online dissemination of SUZA research to relevant national, regional and international stakeholders, e.g. broadcasted from SUZA Television and published as contributions to the MOOC: Sustainable Tourism promoting environmental public health, hosted on the global platform coursera.org. This kind of outreach to the broader public is motivating for further digital course content development too.

Below, Table 2 shows the different approaches to training activities aimed at supporting the need for capacity within MOODLE course design, content development as well as formulating relevant research questions for future studies.

Table 2. Total number of workshop days, participants, the number of courses created in MOODLE and number of students in MOODLE courses per semester

\begin{tabular}{|c|c|c|c|c|c|}
\hline $\begin{array}{l}\text { Workshop title/ } \\
\text { numbers }\end{array}$ & Date & $\begin{array}{l}\text { Workshop } \\
\text { days }\end{array}$ & Participants & Courses & Students \\
\hline $\begin{array}{l}\text { MOODLE course } \\
\text { design }\end{array}$ & $\begin{array}{l}\text { Dec. } 2014- \\
\text { Aug. } 2018\end{array}$ & 14 & 50 & 30 & $500+$ \\
\hline OER integration & $\begin{array}{l}\text { May, 2016, } \\
\text { Aug. } 2017\end{array}$ & 3 & 32 & 11 & \\
\hline $\begin{array}{l}\text { Formulating research } \\
\text { objectives }\end{array}$ & May, 2016 & 3 & 12 & & \\
\hline Video production & Aug. 2017 & 5 & 26 & & \\
\hline $\begin{array}{l}\text { Video post- } \\
\text { production }\end{array}$ & $\begin{array}{l}\text { Aug., Sept. } \\
2017\end{array}$ & 10 & 6 & & \\
\hline
\end{tabular}




\subsection{Activity 2: Pilot and evaluation studies on SUZA's ICT infrastructure, LMS and OER materials}

Since the beginning of the SUZA-BSU partnership, it has been a crucial matter to ensure students' access to digital resources and platforms that enable a satisfying use. This allows the students to get the greatest benefit from their lecturers and ICT staff efforts.

To find the best way for the students to benefit we explored student's usage of and access to SUZA's ICT infrastructure, and a pilot study was undertaken as a survey targeting 352 students out of a total of 2099 SUZA students at the time of the study. The results of this study are shown in Table 3 below. Here you can see that for example only $79.8 \%$ are computer literate, only $40.1 \%$ have access to computers and that $16.2 \%$ lack access to internet. This testifies a needed emphasis on providing computer training as well as providing access to computers and internet connection.

Table 3. Selected results from pilot study on ICT structure and usage

\begin{tabular}{lll}
\hline \multicolumn{1}{c}{352 students } & Yes & No \\
\hline Computer literate (self-evaluation) & $79.8 \%$ & $20.2 \%$ \\
Access to computers in SUZA labs & $40.1 \%$ & $18.4 \%$ \\
& & \\
Internet access in University campus & $83.8 \%$ & $16.2 \%$ \\
Awareness on online education e-resources & $54.5 \%$ & \\
$\begin{array}{l}\text { Number of students using MOODLE for the first } 11 \\
\text { courses designed }\end{array}$ & $81.7 \%$ & \\
\end{tabular}

As part of the earlier mentioned workshops, 11 courses were developed on the MOODLE platform. Another online survey was conducted to evaluate the usage of the platform and the blended learning format for these 11 courses. The study also assessed levels of student satisfaction with the Moodle.

The evaluation showed that out of 155 diploma and bachelor students participating in the first 11 courses, 10 integrated with the Moodle, (81.7\%). The result also shows that most of the students (60\%) use laptops to access the Moodle, $56 \%$ of the students use smartphones, $20.7 \%$ use Desktop computers and $7.4 \%$ of students' access the MOODLE from tablets.

\subsection{Activity 3: Development of SUZA OER guideline}

As many other universities around the world and particularly in developing countries, SUZA suffers from limited teaching and learning materials, inadequate number of teachers and high prices on course materials like traditional printed books. To meet these challenges it can be valuable for the academic institutions to support the so called OER movement which has the potential to reduce instructional costs while providing 
the students as well as academic staff with high quality educational content [1]. And to strengthen, communicate and broaden the use of this kind of OER among lecturers at SUZA, an OER guideline was developed. The guideline covers integration of external produced OER as well as the production of SUZA's own OER, utilization and distribution of OER, including the use of Creative Commons licenses.

A survey among 431 students, as seen in Table 4, shows that around $60 \%$ have had positive experience from OER, around $28 \%$ are neutral while less than $20 \%$ disagree. In this way SUZA would potentially benefit a lot from the usage of OER.

Table 4. Students perception on use of OER as part of their course content

\begin{tabular}{|c|c|c|c|c|}
\hline \multirow[t]{2}{*}{ Perceptions } & \multirow{2}{*}{$\begin{array}{l}\text { Respondents } \\
\text { (Total 431) }\end{array}$} & Agree & Neutral & Disagree \\
\hline & & N (\%) & N (\%) & N (\%) \\
\hline $\begin{array}{l}\text { MOOC contents provided } \\
\text { by instructor were relevant } \\
\text { to this course content. }\end{array}$ & Students & $\begin{array}{l}225 \\
(54)\end{array}$ & 128(30.7) & $64(15.3)$ \\
\hline $\begin{array}{l}\text { You tube video provided by } \\
\text { instructor of this course } \\
\text { elaborate more about most } \\
\text { of the sub-topic. }\end{array}$ & Students & $\begin{array}{l}248 \\
(59)\end{array}$ & 99 (23.6) & $\begin{array}{r}73 \\
(17.4)\end{array}$ \\
\hline $\begin{array}{l}\text { Online tutorial given by } \\
\text { lecturer were very useful. }\end{array}$ & Students & $\begin{array}{r}243 \\
(58.7)\end{array}$ & 98 (23.7) & $\begin{array}{r}73 \\
(17.6)\end{array}$ \\
\hline $\begin{array}{l}\text { Web links provided by } \\
\text { instructor give more } \\
\text { learning opportunities. }\end{array}$ & Students & $\begin{array}{r}253 \\
(60.6)\end{array}$ & $\begin{array}{r}118 \\
(28.3)\end{array}$ & $\begin{array}{r}46 \\
(11.1)\end{array}$ \\
\hline $\begin{array}{l}\text { External forum give me } \\
\text { opportunity to get answer of } \\
\text { my questions than class room } \\
\text { forum. }\end{array}$ & Students & $\begin{array}{r}197 \\
(47.2)\end{array}$ & $\begin{array}{r}135 \\
(32.3)\end{array}$ & $\begin{array}{r}86 \\
(20.5)\end{array}$ \\
\hline $\begin{array}{l}\text { The use of video was very } \\
\text { interesting in this course }\end{array}$ & Students & $\begin{array}{r}268 \\
(63.9)\end{array}$ & $\begin{array}{r}100 \\
(23.9)\end{array}$ & $\begin{array}{c}51 \\
(12.2)\end{array}$ \\
\hline
\end{tabular}

Aside from using OER developed by other institutions SUZA is also producing its own OER as part of earlier activities within the Centre for Digital Learning, CDL. From the three different activities described above, a number of lessons learned can be grouped within five main areas - or questions.

\section{$3 \quad$ Lessons Learned}

\subsection{What human resources are needed?}

From workshop participants' feedback, early experiences showed that lecturers and IT staff did not use digital learning technologies without being given some initial training. This means that only by investing time and resources to support a systematic 
and continuous training, lecturers and supportive IT staff will join the transformation of digitally supported education.

According to the participants, trainings with a practical hand-on approach were found to be the most valuable compared to the more theoretical workshops and lecturers become most motivated when they can easily apply the hands-on training to their own course development.

During the workshops it was also advised that lecturers and IT staff should have easy access to assistance when managing day-to-day inquiries related to the LMS. Ideally each of SUZA's seven campuses should provide technical support staff as well as staff with IT-pedagogical qualifications. Center for ICT services should assign staff to perform regular updates and maintenance of the MOODLE.

To support and to attract attention to the didactic and pedagogical strategies for online and blended learning at SUZA, research should be conducted on specific praxis close teaching activities. Therefore, more SUZA PhD studies in educational technologies are needed to realize this need.

\subsection{What should the ICT-infrastructure look like?}

One of the basic needs to achieve increased and improved access for SUZA students to course materials is to find an efficient way to share and distribute course materials. With this regard, SUZA MOODLE has great potential and is in this way supporting conventional classroom teaching by easing access to a wide range of educational resources such as html-formatted documents, graphics, audio, video, multimedia. Further, it includes features promoting student activation, such as assignment submission, discussion forum, a blog, quiz-creation, grading, an online calendar, announcements and more.

One thing is to install the software but to motivate students as well as teachers' use in high numbers. It is crucial to provide easy access and a user-friendly interface. This is why the MOODLE interface has been redesigned into a version that meets more of the inexperienced teachers and students (20\% of students are computer illiterate, ref. Table 3) needs as well as why the MOODLE was also installed in a mobile version (56\% of students use smartphones, ref. Table 3 ). The mobile version can be accessed via smartphones or tablets.

As for the remaining $44 \%$ of the students with no access to smartphones or computers, it was decided that they should be provided with low cost tablets during BSU III so as to improve equity in accessing this service across students.

Further, to ease access for students it is recommended to build an integration between different IT systems and thereby provide a seamless digital journey for students. For example, an integration between MOODLE and the student registration system would in a user-friendly way lead the students to the online course room. As an additional benefit, easy access saves a lot of time spent on trouble shooting for both admin and academic staff.

Functional plagiarism and a library software are two more areas related to ICTinfrastructure and learning materials and are obviously gaining value if integrated and accessible from the SUZA MOODLE platform. 


\subsection{Should you rely on OER or on own content production - or both?}

A common fear among universities in low income countries has been that the availability of free OER from the world's top universities could lead to a development, where only top universities are producers of OER while the rest of the world's institutions are consumers of OER. Many projects in low income countries have consequently focused on the production of local OER [1]. Experience from the project shows that taking the best from the two worlds could be the best way to go on.

Attention should though be on ensuring teachers' critical approach to OER as well as to maintain production cost and lecturers' time used on content production is low.

This is where Centre for Digital Learning (CDL) has the potential to offer just-intime support that can contribute to saving costs and save lecturers' time at the same time producing materials of high quality.

A guideline for integration, production, utilization and distribution of OER developed at SUZA provide the procedures on all matters regarding the OER within the university in consideration with other policies and guidelines operating within and outside the university.

\subsection{What support is needed from management?}

From the survey, increased use of ICT in education highly depends on a reliable internet connection and equipment for students to access online materials.

Further the use of ICT in education needs more awareness e.g. via a clear institutional vision on digitally supported education to enhance study efficacy and students' performance along with a guideline on minimum standards for the use of SUZA MOODLE.

As human resource is probably the most serious constraint, the university should consider reducing workloads for lecturers and instructors who are participating in developing online materials and blended learning course formats so that they can concentrate on these project activities.

Finally, more funds should be allocated on research studies on the use of digitally supported education. There is a need for research to be conducted to assess the contribution of blended and online courses at SUZA.

\section{Conclusion}

The BSU e-learning project approach, including parallel activities on staff capacity building, hard- and software implementation and institutional development about guides and policies, showcased in this paper, has demonstrated efficacy in driving the development of e-learning capacity at SUZA.

The south-north collaborative effort filling the gap of institutional capacity needed to build a sustainable model for scaling up a skilled use of educational technologies and inclusion of digital learning resources has until now showed successful and is greatly appreciated among staff responsible for a large number of courses. The overall achievement of the activities described have developed beyond expectations with four 
times as many courses on MOODLE and many more course instructors trained than anticipated.

The project has enhanced staff's capacity by training a total of 55 SUZA staff on designing, development and uploading online and blended course materials. Those members of staff have also been acquainted with the use of OER materials in teaching and learning process.

The utilization and integration of OER on existing accredited SUZA courses has been enhanced too.

Challenges also remain, e.g. for students to fully access online materials given, poor internet, and a lack of access to devices. Additionally, far from all SUZA lecturers have been trained in developing and transforming teaching into well-functioning digital supported teaching. In this respect a continued effort is needed to meet a satisfactory level for institutional capacity capable to implement new didactics and pedagogical principles to improve teaching and learning across SUZAs six faculties.

\section{References}

1. A New Way to Motivate Faculty Adoption of OER https://www.insidehighered.com/digital- learning/ last accessed 2019/03/15.

2 Mgeni, M.S., Yunus, S et al (2016). Explore Usage of ICT for Teaching and Learning at SUZA. Unpublished Manuscript.

3. Giving Knowledge for Free: The Emergence of Open Educational Resources. Paris, France: OECD Publishing. 2007. doi:10.1787/9789264032125-en. Retrieved 2019- 03-15. 